\title{
SEROPREVALENCE OF CHLAMYDOPHILA PSITTACI AMONG EMPLOYEES OF TWO GERMAN DUCK FARMS
}

\author{
Raimond Lugert $^{1, * *}$, Uwe Groß ${ }^{1}$, Wycliffe O. Masanta ${ }^{1}$, Gunter Linsel $^{2}$, Astrid Heutelbeck ${ }^{3}$, \\ Andreas E. Zautner ${ }^{1}$ \\ ${ }^{1}$ Institute for Medical Microbiology, University Medical Center Göttingen, Kreuzbergring 57, 37075 Göttingen, Germany \\ ${ }^{2}$ Federal Institute for Occupational Safety and Health (BAuA), Biological Agents, Nöldnerstraße 40-42, 10317 Berlin, Germany \\ ${ }^{3}$ Institute for Occupational, Social and Evironmental Medicine, University Medical Center Göttingen, Waldweg 37b, 37073 Göt- \\ tingen, Germany
}

Received: August 16, 2017; Accepted: August 25, 2017

Psittacosis is a zoonotic infectious disease that is caused by Chlamydophila psittaci. To determine the occupational risk of getting the infection, we investigated the seroprevalence of $C$. psittaci among employees of two German duck farms and two slaughterhouses according to their level of exposure to the pathogen during the years 2010, 2007, and 2004. In summary, we found low seroprevalence $(\approx 8 \%)$ throughout the study population almost irrespective of the duty of a given worker. Surprisingly, in 2010 , the anti-C. psittaci-specific antibody prevalence in the group of slaughterer (38.9\%) was significantly increased in comparison to the non-exposed employees ( $p=0.00578$ ). This indicates that individuals in the surrounding of slaughterhouses exposed especially to aerosols containing $C$. psittaci elementary bodies bear a greater occupational risk of getting infected.

Keywords: Chlamydophila psittaci, psittacosis, duck farms, serology, seroprevalence

\section{Introduction}

Chlamydophila psittaci, an obligate intracellular pathogen, is the causative agent of psittacosis, also referred to as ornithosis, and parrot fever. This bacterial species, which can be separated in altogether 13 genotypes according to the state of their outer membrane protein A (ompA) [1], are widespread in poultry industry where they represent a major factor of economic damage [2, 3]. Consequently, poultry industry represents an important avenue for the transmission of the pathogen from birds to humans. $C$. psittaci has also been found in domesticated pets, e.g., cats, and in livestock including sheep, cattle, and goat [4-6]. Nevertheless, it is now known that $C$. psittaci typically infects birds while mammals serve as transient hosts [7].
The relevance of $C$. psittaci as a human pathogen is constantly decreasing in Germany with only 9 manifest cases in the year 2014. Due to improved surveillance programs, the species dwells in the shadow of its more prominent relatives, Chlamydia trachomatis and Chlamydophila pneumoniae [8]. Nevertheless, psittacosis in humans is a serious disease that may have a fatal outcome according to the European Directive 2000/54/EC where it is classified as pathogen of "risk group 3" (can cause severe human disease and present a serious hazard to workers). Symptoms of an infection with $C$. psittaci usually begin after an incubation period of 5-14 days and include high fever (up to $40.5^{\circ} \mathrm{C}$ ), headache, chills, myalgia, non-productive coughing, and, occasionally, contamination of sputum with traces of blood. In addition, the disease might be accompanied with non-specific symptoms like vomiting, ab-

\footnotetext{
* Corresponding author: Raimond Lugert; University Medical Center Göttingen, Institute for Medical Microbiology, Kreuzbergring 57, 37075 Göttingen, Germany; Phone: 49-551-395869; Fax: 49-551-395861; Email: rlugert@gwdg.de

This is an open-access article distributed under the terms of the Creative Commons Attribution-NonCommercial 4.0 International License (https://creativecommons.org/licenses/by-nc/4.0/), which permits unrestricted use, distribution, and reproduction in any medium for non-commercial purposes, provided the original author and source are credited, a link to the CC License is provided, and changes - if any - are indicated.
} 
dominal pain, or diarrhea, but also, an inapparent course of the disease is frequent. Because cases of human psittacosis are rare, diagnosis of $C$. psittaci does not belong to the routine diagnostic management in most laboratories to detect pneumonia-causing agents. This, in turn, increases the hazard of a fatal outcome if the pathogen is not detected soon and, accordingly, the patient is not treated properly [9-11]. Retrospective studies of ornithosis pneumonia in poultry slaughterhouses have shown the highest risk of contracting the disease in newly hired employees with closed contact to the living poultry [12]. Several reports that describe shedding of the pathogen within a population of domesticated ducks and the risk for the transmission from birds to humans have been published. Cong and coworkers [13] demonstrated the $C$. psittaci seroprevalence in caged ducks to be significantly lower than in free-range ducks, which might be explained by the fact that freerange ducks are more likely to come into contact with the pathogen via other birds. Monitoring studies in both breeder flocks and mule duck flocks suggested that ducklings inherited only low infection levels, whereas heavy C. psittaci shedding was detected in the mule duck flocks. Since the infection of the ducks was asymptomatic and, thus, remains unrecognized, $C$. psittaci was judged to pose as a potential risk for the workers in these farms [14]. Indeed, the risk of people with occupational-dependent contact to birds has been shown to be increased for the development of an atypical pneumonia $[15,16]$. Accordingly, Hulin and coworkers [17], investigating cloacal swabs, air samples, and environmental samples by real-time qPCR, described disinfection to be the most important practice to reduce the prevalence of $C$. psittaci in ducks.

Serological tests are well established to diagnose a wide range of infections irrespective of their cause. The primary immune response after an infection with Chlamydophilia sp. consists of IgM antibodies, which are followed by antibodies of the classes IgA and IgG. In our study, we carried out enzyme-linked immunosorbent assays (ELISAs) and micro-immunofluorescent (MIF) assays for the detection of Chlamydophila-specific and C. psittaci-specific IgA and IgG antibodies to determine the anti-C. psittaci-specific seroprevalence in workers of two duck farms and two slaughterhouses in Germany. The aim of this study was to investigate the hazard to become infected with C. psittaci depending on the particular function of these employees and the options to reduce infections with the pathogen by occupational health and safety (OHS) measures. For this, we have investigated three groups of workers in the years 2010, 2007, and 2004.

\section{Methods}

\section{Study design and ethical permission}

The study was conceived as prospective follow-up study as mentioned before in the publication of Masanta and coworkers [18]. The study was approved by the ethics commission of the Medical Association of Berlin, Germany (Eth-013/07). Participants of the study were employees from two duck farms and two slaughterhouses in Germany. These employees were classified in three categories. The first group encompassed non-exposed individuals with no contact to ducks and includes office workers, cereal suppliers, craftsmen, drivers, or technicians. A second group consisted of exposed subjects like aviary (including hatchery) workers. Finally, the third category was composed of highly exposed slaughterhouse (including bird

Table 1. Individuals investigated in this study regarding their function and corresponding level of exposure to C. psittaci

\begin{tabular}{|c|c|c|c|c|c|}
\hline \multirow[t]{2}{*}{ Group of subjects } & \multirow[t]{2}{*}{ Description } & \multirow[t]{2}{*}{ Category } & \multicolumn{3}{|c|}{ No. of workers } \\
\hline & & & 2010 & 2007 & 2004 \\
\hline Management & No exposure & Non exposed & 13 & 6 & 11 \\
\hline Management (local) & Low/no exposure* & Non exposed & 11 & 3 & 6 \\
\hline General services** & Low/mean exposure & Non exposed & 12 & 7 & 7 \\
\hline Cereal service staff & Low/no exposure & Non exposed & 0 & 1 & 0 \\
\hline Aviary workers & High exposure & Exposed aviary & 45 & 19 & 30 \\
\hline Hatchery workers & High exposure to ducklings & Exposed aviary & 7 & 12 & 9 \\
\hline Bird receipt & Very high exposure & Exposed slaughterer & 10 & 2 & 6 \\
\hline Slaughterer & High exposure & Exposed slaughterer & 8 & 3 & 3 \\
\hline Sum no exposure & & & 36 & 17 & 24 \\
\hline Sum exposure & & & 70 & 36 & 48 \\
\hline Sum exposed (aviary) & & & 52 & 31 & 39 \\
\hline Sum exposed (slaughterer) & & & 18 & 5 & 9 \\
\hline Sum all & & & 106 & 53 & 72 \\
\hline
\end{tabular}

*Minor contact to ducks or duck products cannot be excluded

**Including, e.g., craftsmen or technicians with very limited contact to ducks or related products (ca. 10\% of their working hours) 
receipt) workers with close contact to ducks or duck meat due to their particular function. Since 2008, other than aviary and hatchery workers, that means slaughterer and bird receipt workers additionally handle thousands of animals of different herds of different stables. Blood samples were drawn in the autumn season during a period from September 28 to November 14 in 2004, 2007, and 2010. During the 6 years, a sum of 231 sera of 94 male and 67 female participants were collected and analyzed; 70 drawn in 2004, 53 drawn in 2007, and 106 drawn in 2010. The mean age of all participants was $39( \pm 11)$, and the median age was 40 in 2004. Details are listed in Table 1. Additionally, each participant has been asked to fill out a questionnaire and provide information on tenure in a duck processing plant in months, respiratory symptoms, smoking status, and pneumonia in his/ her medical history. This information is summarized in Table 2. Occupational health and safety (OHS) protective measures were carried out taking account of TRBA 230 (Committee for Biological Agents (ABAS) 2007), which is a technical rule concretizing the German Ordinance on Safety and Health Protection at Work involving Biological Agents (BioStoffV). The aim of these recommendations is the minimization of the exposure of employees towards biological agents by, first of all, suitable technical and organizational measures. At last, breathing masks or air purifying systems as personal protective sanctions should be supplied. Nevertheless, the protective measures are not able to prevent human infection in this working branch.

\section{Serological analysis}

Blood samples gained in the years 2004, 2007, and 2010 were tested for the presence of $C$. psittaci IgA and IgG antibodies. The sera were analyzed by two different serological methods: the Serion ELISA classic Chlamydia IgA/IgG (Virion/Serion $\mathrm{GmbH}$, Würzburg, Germany) that is based on LPS-free elementary bodies (EBs) of $C$. psittaci genotype D Borg and the micro-immunofluorescence assays Chlamydia MIF IgA and Chlamydia MIF IgG (Focus Diagnostics, Cypress, USA) that detects antibodies against LPS-liberated EBs from strains 6BC and DD34 of $C$. psittaci genotype A [19] as well as antibodies against $C$. trachomatis and $C$. pneumoniae.

\section{Statistical analysis}

The $\chi^{2}$ test was carried out to test for significant differences. Thereby, $p$ values of $<0.05$ were judged to be significant.

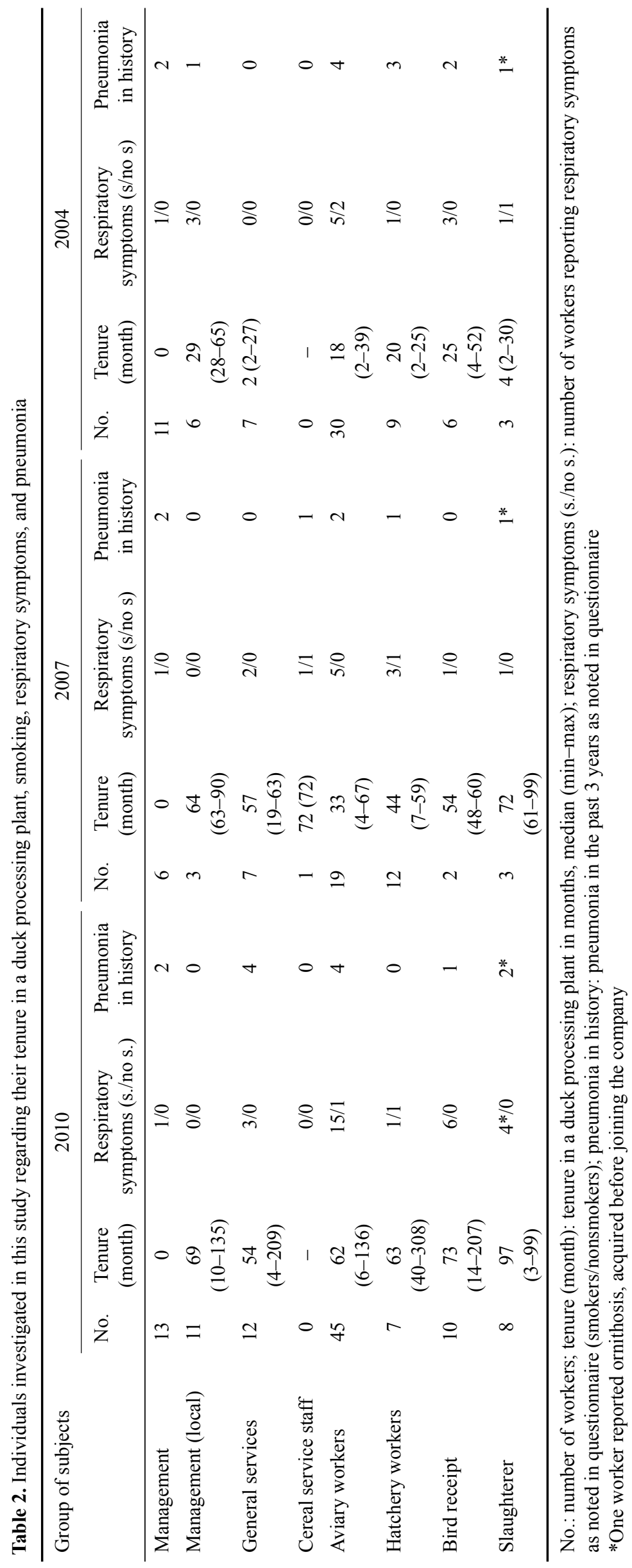

European Journal of Microbiology and Immunology 


\section{Ethics statement}

The study was approved by the ethics commission of the Medical Association of Berlin, Germany (Eth-013/07).

\section{Results}

Each participant of the study was asked to complete a medical questionnaire every year. As indicated in $T a$ ble 2, the number of workers with respiratory symptoms or pneumonia in the medical history was increased in the group of aviary and bird receipt workers. Taking the smoking status into account, it was evident that these respiratory symptoms were attributable to smoking and not to occupational exposure. At best, one can assume additive effects of smoking and occupational exposure. It has to be noted that one slaughterer reported ornithosis, acquired before joining the company.

Performing ELISA assays for the detection of antiChlamydia/Chlamydophila spp.-specific antibodies, we obtained different percentages of individuals with $\operatorname{IgA}$ and IgG antibody responses, respectively (Table 3). However, only regarding the IgA antibodies in the samples from the year 2010, we detected a significant difference of seroprevalence in the group of slaughterer $(38.9 \% ; p=0.00578)$ on one hand and of aviary workers $(0.0 \% ; p=0.03441)$ on the other hand compared to non-exposed employees $(8.3 \%)$. The immune response against $C$. psittaci was investigated employing immunofluorescence tests (IFTs) for the detection of specific IgA and IgG antibodies (Table 4). Overall, the seroprevalence of non-exposed as well as exposed aviary workers or slaughterer was low irrespective from the year of sampling. However, there was one exception: in accordance with the results of the ELISA assays, the seroprevalence $(\operatorname{Ig} \mathrm{A}+\operatorname{IgG})$ in the category of exposed slaughterer was increased in the year 2010 to $27.8 \%(5 / 18$, $p=0.02169)$, which was significant in comparison to the non-exposed workers $(2 / 36,5.6 \%)$.

Combining the results from the ELISA assays with the IFTs, antibodies against $C$. pneumoniae, but also $C$. trachomatis, were detected in several samples, indicating possible cross-reactions rather than infections with $C$. psittaci. In respect of non-exposed individuals in the year 2010, two of 36 workers possessed antibodies against C. psittaci performing IFTs. One of the two exhibited IgA and

Table 3. Number and percentage of individuals with IgA and/or IgG antibodies against Chlamydia/Chlamydophilia spp. determined using the Serion ELISA

\begin{tabular}{|c|c|c|c|c|c|c|c|c|c|}
\hline \multirow[t]{2}{*}{ Category } & \multicolumn{3}{|c|}{2010} & \multicolumn{3}{|c|}{2007} & \multicolumn{3}{|c|}{2004} \\
\hline & $\operatorname{IgA}$ & $\operatorname{IgG}$ & $\operatorname{Ig} \mathrm{A}+\mathrm{G}$ & $\operatorname{IgA}$ & $\mathrm{IgG}$ & $\operatorname{Ig} A+G$ & $\operatorname{IgA}$ & $\operatorname{IgG}$ & $\mathrm{IgA}+\mathrm{G}$ \\
\hline No exposure & $\begin{array}{c}3 / 36 \\
(8.3 \%)\end{array}$ & $\begin{array}{c}29 / 36 \\
(80.6 \%)\end{array}$ & $\begin{array}{c}29 / 36 \\
(80.6 \%)\end{array}$ & $\begin{array}{c}1 / 17 \\
(5.9 \%)\end{array}$ & $\begin{array}{c}11 / 17 \\
(64.7 \%)\end{array}$ & $\begin{array}{c}11 / 17 \\
(64.7 \%)\end{array}$ & $\begin{array}{c}2 / 24 \\
(8.3 \%)\end{array}$ & $\begin{array}{c}15 / 24 \\
(62.5 \%)\end{array}$ & $\begin{array}{c}16 / 24 \\
(66.7 \%)\end{array}$ \\
\hline $\begin{array}{l}\text { Exposure } \\
\text { (aviary workers) }\end{array}$ & $\begin{array}{l}0 / 52 * \\
(0.0 \%)\end{array}$ & $\begin{array}{c}33 / 52 \\
(63.5 \%)\end{array}$ & $\begin{array}{c}33 / 52 \\
(63.5 \%)\end{array}$ & $\begin{array}{c}1 / 31 \\
(3.2 \%)\end{array}$ & $\begin{array}{c}20 / 31 \\
(64.5 \%)\end{array}$ & $\begin{array}{c}20 / 31 \\
(64.5 \%)\end{array}$ & $\begin{array}{c}2 / 39 \\
(5.1 \%)\end{array}$ & $\begin{array}{c}22 / 39 \\
(56.4 \%)\end{array}$ & $\begin{array}{c}22 / 39 \\
(56.4 \%)\end{array}$ \\
\hline $\begin{array}{l}\text { Exposure } \\
\text { (slaughterer) }\end{array}$ & $\begin{array}{c}7 / 18^{*} \\
(38.9 \%)\end{array}$ & $\begin{array}{c}15 / 18 \\
(83.3 \%)\end{array}$ & $\begin{array}{c}15 / 18 \\
(83.3 \%)\end{array}$ & $\begin{array}{c}1 / 5 \\
(20.0 \%)\end{array}$ & $\begin{array}{c}5 / 5 \\
(100 \%)\end{array}$ & $\begin{array}{c}5 / 5 \\
(100 \%)\end{array}$ & $\begin{array}{c}2 / 9 \\
(22.2 \%)\end{array}$ & $\begin{array}{c}8 / 9 \\
(88.9 \%)\end{array}$ & $\begin{array}{c}8 / 9 \\
(88.9 \%)\end{array}$ \\
\hline Exposure sum & $\begin{array}{c}7 / 70 \\
(10.0 \%)\end{array}$ & $\begin{array}{c}48 / 70 \\
(68.6 \%)\end{array}$ & $\begin{array}{c}48 / 70 \\
(68.6 \%)\end{array}$ & $\begin{array}{c}2 / 36 \\
(5.6 \%)\end{array}$ & $\begin{array}{c}25 / 36 \\
(69.4 \%)\end{array}$ & $\begin{array}{c}25 / 36 \\
(69.4 \%)\end{array}$ & $\begin{array}{c}4 / 48 \\
(8.3 \%)\end{array}$ & $\begin{array}{c}30 / 48 \\
(62.5 \%)\end{array}$ & $\begin{array}{c}30 / 48 \\
(62.5 \%)\end{array}$ \\
\hline
\end{tabular}

*The asterisks indicate significant $p$ values of $<0.05$ (a missing asterisk indicates a nonsignificant difference) in comparison to the no exposure group

Table 4. Number and percentage of individuals with IgA and/or IgG antibodies against $C$. psittaci determined using the Focus Diagnostics MIF

\begin{tabular}{|c|c|c|c|c|c|c|c|c|c|}
\hline \multirow[t]{2}{*}{ Category } & \multicolumn{3}{|c|}{2010} & \multicolumn{3}{|c|}{2007} & \multicolumn{3}{|c|}{2004} \\
\hline & IgA & $\operatorname{IgG}$ & $\operatorname{Ig} \mathrm{A}+\mathrm{G}$ & IgA & $\operatorname{IgG}$ & $\operatorname{Ig} A+G$ & IgA & $\operatorname{IgG}$ & $\operatorname{IgA}+\mathrm{G}$ \\
\hline No exposure & $\begin{array}{c}2 / 36 \\
(5.6 \%)\end{array}$ & $\begin{array}{c}1 / 36 \\
(2.8 \%)\end{array}$ & $\begin{array}{c}2 / 36 \\
(5.6 \%)\end{array}$ & $\begin{array}{c}0 / 17 \\
(0.0 \%)\end{array}$ & $\begin{array}{c}1 / 17 \\
(5.9 \%)\end{array}$ & $\begin{array}{c}1 / 17 \\
(5.9 \%)\end{array}$ & $\begin{array}{c}1 / 24 \\
(4.2 \%)\end{array}$ & $\begin{array}{c}0 / 24 \\
(0.0 \%)\end{array}$ & $\begin{array}{c}1 / 24 \\
(4.2 \%)\end{array}$ \\
\hline $\begin{array}{l}\text { Exposure (aviary } \\
\text { workers) }\end{array}$ & $\begin{array}{c}0 / 52 \\
(0.0 \%)\end{array}$ & $\begin{array}{c}0 / 52 \\
(0.0 \%)\end{array}$ & $\begin{array}{c}0 / 52 \\
(0.0 \%)\end{array}$ & $\begin{array}{c}0 / 31 \\
(0.0 \%)\end{array}$ & $\begin{array}{c}3 / 31 \\
(9.7 \%)\end{array}$ & $\begin{array}{c}3 / 31 \\
(9.7 \%)\end{array}$ & $\begin{array}{c}1 / 39 \\
(2.6 \%)\end{array}$ & $\begin{array}{c}2 / 39 \\
(5.1 \%)\end{array}$ & $\begin{array}{c}3 / 39 \\
(7.7 \%)\end{array}$ \\
\hline $\begin{array}{l}\text { Exposure } \\
\text { (slaughterer) }\end{array}$ & $\begin{array}{c}2 / 18 \\
(11.1 \%)\end{array}$ & $\begin{array}{c}3 / 18 \\
(16.7 \%)\end{array}$ & $\begin{array}{c}5 / 18^{*} \\
(27.8 \%)\end{array}$ & $\begin{array}{c}0 / 5 \\
(0.0 \%)\end{array}$ & $\begin{array}{c}0 / 5 \\
(0.0 \%)\end{array}$ & $\begin{array}{c}0 / 5 \\
(0.0 \%)\end{array}$ & $\begin{array}{c}1 / 9 \\
(11.1 \%)\end{array}$ & $\begin{array}{c}0 / 9 \\
(0.0 \%)\end{array}$ & $\begin{array}{c}1 / 9 \\
(11.1 \%)\end{array}$ \\
\hline Exposure sum & $\begin{array}{c}2 / 70 \\
(7.4 \%)\end{array}$ & $\begin{array}{c}3 / 70 \\
(4.3 \%)\end{array}$ & $\begin{array}{c}5 / 70 \\
(7.1 \%)\end{array}$ & $\begin{array}{c}0 / 36 \\
(0.0 \%)\end{array}$ & $\begin{array}{c}3 / 36 \\
(8.3 \%)\end{array}$ & $\begin{array}{c}3 / 36 \\
(8.3 \%)\end{array}$ & $\begin{array}{c}2 / 48 \\
(4.2 \%)\end{array}$ & $\begin{array}{c}2 / 48 \\
(4.2 \%)\end{array}$ & $\begin{array}{c}4 / 48 \\
(8.3 \%)\end{array}$ \\
\hline
\end{tabular}

*The asterisks indicate significant $p$ values of $<0.05$ (a missing asterisk indicates a nonsignificant difference) in comparison to the no exposure group 
IgG antibodies but was also IgG positive for C. trachomatis and $C$. pneumoniae. The other employee was only IgA-positive for $C$. psittaci but had a strong IgG response against $C$. pneumoniae. In the years 2007 and 2004, we had only one employee from the non-exposed category, respectively, with an antibody response against $C$. psittaci. One was IgG positive (year 2007), with an additional IgG against $C$. trachomatis and $C$. pneumoniae, while the other (year 2004) possessed IgA antibodies against $C$. psittaci along with an $\mathrm{IgG}$ response against $C$. trachomatis. Two of three (out of 31) exposed aviary workers in the year 2007 were IgG-positive solely against $C$. psittaci, whereas the third one also possessed IgG antibodies against $C$. trachomatis and C. pneumoniae as well. In three out of 39 samples in the year 2004, anti-C. psittaci antibodies were detected. Thereof, one subject had an IgA response exclusively against $C$. psittaci, whereas two individuals were indeed IgG positive, however, not only against $C$. psittaci but also for $C$. trachomatis alone or for $C$. trachomatis and $C$. pneumoniae. In contrast to the non-exposed group and the aviary workers participating in this study, the samples from the exposed slaughterer of 2010 showed a significantly higher seroprevalence towards C. psittaci (5/18), compared to the samples in the years $2007(0 / 5)$ and 2004 (1/9). In case of the individual in the year 2004, an IgA response against $C$. psittaci was accompanied with an IgA and IgG seroprevalence against $C$. pneumoniae. Three of the five seropositive employees in the year 2010 possessed anti-chlamydial antibodies solely against $C$. psittaci, whereas the remaining two individuals were also IgGpositive for $C$. pneumoniae beside IgG antibodies against C. psittaci.

\section{Discussion}

C. psittaci-caused diseases in humans are rare compared to the number of C. pneumoniae or C. trachomatis infections. Since the major sources for the infection with $C$. psittaci are birds, poultry farming companies and slaughterhouses are supposed to be prominent places for transmission. Moreover, zoonotic transfer of the pathogen to humans after a single contact with an infected bird cannot be excluded [20, 21].

Indeed, in our study, the seroprevalence in the study population was low, indicating only a minor hazard to become infected with $C$. psittaci. In addition, when we compared the seroprevalence of non-exposed employees with the seroprevalence of exposed aviary workers and highly exposed slaughterer, we detected significant differences only in samples drawn in the year 2010 with $27.8 \%$ of the slaughterer to possess $\operatorname{IgA}$ and $\operatorname{IgG}$ antibodies against C. psittaci compared to $5.6 \%$ of the control group. Chlamydia and Chlamydophila are genera of obligate intracellular bacteria whose entire development cycle takes place inside a vacuole, entitled an inclusion body [22]. These inclusion bodies, in turn, contain a mix of EBs and reticulate bodies (RBs), which are released during the butchering of birds due to tissue rupture and cellular damage. Since the EBs are indeed metabolically dormant but infectious, the ultimate contact of the slaughterer to the ducks and in particular to the aerosols incurred in the slaughter process favors the infection of this occupational group. A second reason for the differences in anti-C. psittaci-specific antibody seroprevalence of slaughterer in the years 2007 and 2004 compared to 2010 should be the longer tenure. It was with an average of 97 months in 2010, significantly longer compared to the years before as well as in comparison to the other groups of participants (see Table 2). Additionally, it must be mentioned that, in 2010, bird receipt workers and slaughterer had to process ducks originating not only from the own associated duck farm but also from duck farms associated with other companies. That was not the case in 2007 and 2004. In contrast, in the study of Harkinezhad and coworkers [19], the seroprevalence of $C$. psittaci in a healthy population with contact to domestic birds was higher. This might be explained by the close contact of pet owners to, e.g., parakeets, parrots, or canary birds. In addition, the contact of humans to Psittaciformes in particular seems to facilitate the transmission of the pathogen to humans [23]. Since the verification of C. psittaci does not belong to routine diagnostics in many laboratories and serological assays are error-prone, a community-acquired pneumonia (CAP) caused by this pathogen might not be detected straightaway. To counteract this problem, empirical therapy using antibiotics also for the eradication of intracellular pathogens should be given. Thereby, macrolides, tetracyclines, or quinolones represent the best empirical treatment due to their high intracellular concentration and good antimicrobial activity. In case of intolerance to these antibiotics, levofloxacin or moxifloxacin are available $[24,25]$. Employees in poultry farms and processing plants and their primary care doctors must be informed about the risk of work-related $C$. psittaci infections to initiate the right therapy as soon as possible.

Cross-reactivity between chlamydial species applying commercial MIF assays has been described before. Thereby, the Labsystems MIF for the detection of IgG antibodies against $C$. pneumoniae was shown to exhibit significant cross-reactivity to $C$. psittaci [26]. Another MIF assay using chlamydial serovars from human pathogenic species facilitates cross-reacting due to the usage of genus-specific antigens [27]. In our study, we applied the Serion ELISA classic tests and the Chlamydia MIF IgA and Chlamydia MIF IgG assays from Focus Diagnostics to detect $C$. psittaci infections. Although the Serion ELISA is based on EBs of $C$. psittaci genotype D Borg, it is supposed to be only genus specific, and their validity is restricted to detect chlamydial infections in general. In contrast, the setup of the MIF assays using purified EBs allows species differentiation. However, these assays permit cross-reactions since the major outer membrane protein (MOMP) contains both species- and genus-specific epitopes. Consequently, antibodies detected against $C$. psittaci can be $C$. pneumoniae or $C$. trachomatis derived. Taken together, these findings do not express false-positive values regarding the 
seroprevalence for $C$. psittaci per se, but cross-reactions after contact with other Chlamydia/Chlamydophilia species have to be considered and also factual parallel or sequential double infections especially with relatively high prevalent $C$. pneumonia (seroprevalence of 40-60\%) and also $C$. trachomatis have to be assumed [28]. Otherwise, since the MIF assays are composed of genotype A EBs of strains 6BC and DD34 [19], other C. psittaci genotypes might not be recognized by the MIF assays but could be detected using the genus-specific Serion ELISA tests.

\section{Funding sources}

This study was financed by the "Bundesanstalt für Arbeitsschutz und Arbeitsmedizin (BAuA)", Berlin, Germany, and publication of the study by the publication fund of the Georg August University Göttingen, Germany and the Open Access support program of the "Deutsche Forschungsgemeinschaft”.

\section{Authors' contribution}

R.L. drafted and wrote the article. A.E.Z. conceived the study idea and performed all mathematical analysis. W.O.M. carried out the serological assays. U.G., G.L., and A.H. participated in the study design and helped in drafting the article. All authors read and corrected the article.

\section{Conflict of interest}

The authors affirm that they have no competing interests.

\section{Acknowledgements}

The authors thank Lena Preiser for her support by helping to perform the immunofluorescence assays.

\section{References}

1. Mitchell SL, Wolff BJ, Thacker WL, Ciembor PG, Gregory CR, Everett KDE, Ritchie BW, Winchell JM: Genotyping of Chlamydophila psittaci by real-time PCR and high-resolution melt analysis. J Clin Microbiol 47, 175-181 (2009)

2. European Commission Health and Consumer Protection Directorate-General. Avian chlamydiosis as a zoonotic disease and risk reduction strategies [Online]. 2002, pp 1-26, Report No.: SANCO/AH/R26/2002. http://www.kiza.nl/ sites/default/files/documenten/Avian\%20chlamydiosis\%202002\%20EU.pdf

3. Sachse K, Laroucau K, Vorimore F, Magnino S, Feige J, Müller W, Kube S, Hotzel H, Schubert E, Slickers P, Ehricht R: DNA microarray-based genotyping of Chla- mydophila psittaci strains from culture and clinical samples. Vet Microbiol 135, 22-30 (2009)

4. Kemmerling K, Müller U, Mielenz M, Sauerwein H: Chlamydophila species in dairy farms: Polymerase chain reaction prevalence, disease association, and risk factors identified in a cross-sectional study in western Germany. J Dairy Sci 92, 4347-4354 (2009)

5. Pantchev A, Sting R, Bauerfeind R, Tyczka J, Sachse K: Detection of all Chlamydophila and Chlamydia spp. of veterinary interest using species-specific real-time PCR assays. Comp Immunol Microbiol Infect Dis 33, 473-484 (2010)

6. Lenzko H, Moog U, Henning K, Lederbach R, Diller R, Menge C, Sachse K, Spraque LD: High frequency of chlamydial co-infections in clinically healthy sheep flocks. BMC Vet Res 7, 29 (2011)

7. Knittler MR, Sachse K: Chlamydia psittaci: update on an underestimated zoonotic agent. Pathog Dis 73, 1-15 (2015)

8. Robert Koch-Institut (2015): Infektionsepidemiologisches Jahrbuch Meldepflichtiger Krankheiten für 2014.

9. Levison DA, Guthrie W, Ward C, Green DM, Robertson PG: Infective endocarditis as part of psittacosis. Lancet 2, 844-8477 (1971)

10. Carr-Locke DL, Mair HJ: Neurological presentation of psittacosis during a small outbreak in Leicestershire. $\mathrm{Br}$ Med J. 2, 853-854 (1976)

11. Senn L, Greub G: Local Newspaper as a diagnostic aid for psittacosis: a case report. Clin Infect Dis 46, 1931-1932 (2008)

12. Manke H, Müller R, Huke M, Lederer P: Ornithoseausbruch in einer Geflügelschlachterei: Erkenntnisse für den Arbeitsschutz. Betriebsarzt Arbeitsmedizin Sozialmedizin Umweltmed 35, 120-124 (2000)

13. Cong W, Huang SY, Zhang XY, Zhou DH, Xu MJ, Zhao Q, Song HQ, Zhu XQ, Qian AD: Seroprevalence of Chlamydia psittaci infection in market-sold adult chickens, ducks and pigeons in north-western China. J Med Microbiol 62, 12111214 (2013)

14. Vorimore F, Thébault A, Poisson S, Cléva D, Robineau J, de Barbeyrac B, Durand B, Laroucau K: Chlamydia psittaci in ducks: a hidden health risk for poultry workers. Pathog Dis 73, 1-9 (2015)

15. Huminer D, Pitlik S, Kitayin D, Weissman Y, Samra Z: Prevalence of Chlamydia psittaci infection among persons who work with birds. Isr J Med Sci 28, 739-741 (1992)16.

16. Hinton D, Shipley A, Galvin J, Harkin J, Brunton R: Chlamydiosis in workers at a duck farm and processing plant. Aust Vet J 70, 174-176 (1993)

17. Hulin V, Bernard P, Vorimore F, Aaziz R, Cléva D, Robineau J, Durand B, Angelis L, Siakour VI, Laroucau K: Assessment of Chlamydia psittaci shedding and environmental contamination as potential sources of worker exposure throughout the mule duck breeding process. Appl Environ Microbiol 82, 1504-1518 (2016)

18. Masanta WO, Lugert R, Groß U, Linsel G, Heutelbeck A, Zautner AE: Seroprevalence of Campylobacter-specific antibodies in two German duck farms - A prospective follow-up study. Eur J Microbiol Immunol 6, 118-123 (2016)

19. Harkinezhad T, Verminnen K, De Buyzere M, Rietzschel E, Bekaert S, Vanrompay D: Prevalence of Chlamydophila psittaci infections in a human population in contact with domestic and companion birds. J Med Microbiol 58, 1207$1212(2009)$ 
20. Harkinezhad T, Verminnen K, Van Droogenbroeck C, Vanrompay D: Chlamydophila psittaci genotype E/B transmission from African grey parrots to humans. J Med Microbiol 56, 1097-1100 (2007)

21. Matsui T, Nakashima K, Ohyama T, Kobayashi J, Arima Y, Kishimoto T, Ogawa M, Cai Y, Shiga S, Ando S, Kurane I, Tabara K, Itaqaki A, Nitta N, Fukushi H, Matsumoto A, Okabe N: An outbreak of psittacosis in a bird park in Japan. Epidemiol Infect 136, 492-495 (2008)

22. Abdelrahman YM, Belland RJ: The chlamydial developmental cycle. FEMS Microbiol Rev 29, 949-959 (2005)

23. Heddema ER, van Hannen EJ, Duim B, de Jongh BM, Kaan JA, van Kessel R, Lumaii JT, Visser CE, VandenbrouckeGrauls CM: An outbreak of psittacosis due to Chlamydophila psittaci genotype A in a veterinary teaching hospital. J Med Microbiol 55, 1571-1575 (2006)

24. Bartlett JG, Dowell SF, Mandell LA, File TM, Musher DM, Fine MJ: Practice guidelines for the management of community-acquired pneumonia in adults. Clin Infect Dis 31, 347-382 (2000)
25. Cillóniz C, Torres A, Niederman M, van der Eerden M, Chalmers J, Welte T, Blasi F: Community-acquired pneumonia related to intracellular pathogens. Intensive Care Med 42, 1374-1386 (2016)

26. Messmer TO, Martinez J, Hassouna F, Zell ER, Harris W, Dowell S, Carlone GM: Comparison of two commercial microimmunofluorescence kits and an enzyme immunoassay kit for detection of serum immunoglobulin G antibodies to Chlamydia pneumoniae. Clin Diagn Lab Immunol 8, 588-592 (2001)

27. Wong YK, Sueur JM, Fall CH, Orfila J, Ward ME: The species specificity of the microimmunofluorescence antibody test and comparisons with a time resolved fluoroscopic immunoassay for measuring IgG antibodies against Chlamydia pneumoniae. J Clin Pathol. 52, 99-102 (1999)

28. Peeling RW, Brunham RC: Chlamydiae as pathogens: new species and new issues. Emerg Infect Dis 2, 307-319 (1996) 